This item was submitted to Loughborough's Research Repository by the author.

Items in Figshare are protected by copyright, with all rights reserved, unless otherwise indicated.

\title{
Photovoltaic energy competitiveness and risk assessment for the South African residential sector
}

PLEASE CITE THE PUBLISHED VERSION

http://dx.doi.org/10.1002/pip.2757

\author{
PUBLISHER \\ (c) John Wiley \& Sons
}

\section{VERSION}

AM (Accepted Manuscript)

\section{PUBLISHER STATEMENT}

This work is made available according to the conditions of the Creative Commons Attribution-NonCommercialNoDerivatives 4.0 International (CC BY-NC-ND 4.0) licence. Full details of this licence are available at: https://creativecommons.org/licenses/by-nc-nd/4.0/

\section{LICENCE}

CC BY-NC-ND 4.0

\section{REPOSITORY RECORD}

Betz, Stephanie, Silvia Caneva, Ingrid Weiss, and Paul Rowley. 2019. "Photovoltaic Energy Competitiveness and Risk Assessment for the South African Residential Sector". figshare. https://hdl.handle.net/2134/21080. 


\title{
Photovoltaic Energy Competitiveness and Risk Assessment for the South African Residential Sector
}

Author for correspondence: Stephanie Betz, WIP Renewable Energies, Sylvensteinstraße 2, 81369 Munich, Germany, Phone: +49 8972012 732, E-mail: stephanie.betz@wip-munich.de

\author{
Co-authors: S. Caneva ${ }^{1)}$, I. Weiss ${ }^{1)}$, P. Rowley ${ }^{2)}$
}

1)WIP Renewable Energies, Sylvensteinstraße 2, 81369 Munich, Germany

2) Centre for Renewable Energy Systems Technology (CREST), Loughborough University, Epinal Way, Loughborough, Leicestershire, UK, LE113TU

\begin{abstract}
The establishment of new photovoltaic (PV) markets in emerging economies represents a business development opportunity for expansion outside traditional energy markets. Appropriate assessment of PV market competitiveness is thus necessary in order to inform policy and regulatory development, and in order to manage risks related to investment. This paper presents an evaluation of PV energy competitiveness using a case study of the emerging residential PV market in South Africa. Competitiveness is defined in light of the risks associated with the financial performance of domestic grid-connected rooftop PV considering the current market status together with three proposed business models, namely net-metering, net-billing, and an energy savings performance contract framework. Financial performance is evaluated in terms of a socket parity evaluation together with a discounted net cash flow analysis. Investment risk assessment was facilitated using a Monte Carlo simulation. The results indicate the highest potential profitability for the energy savings performance contract model, which includes PV system ownership by an energy services company. It is also shown that appropriate application of risk modelling has the potential to inform decisions by investors and policy makers alike that result in improved policy and business solutions that are able to support increased residential PV energy market competitiveness without the need for explicit subsidy frameworks.
\end{abstract}

Keywords: PV Competitiveness, Risk Assessment, Financial Model, Monte Carlo, South Africa, Socket Parity

\section{Introduction}

Solar photovoltaic (PV) sector growth has been showing signs of stagnation in its most mature markets. The number of new installed capacity in Europe is decreasing every year. $17.7 \mathrm{GW}$ connected in 2012, $10.5 \mathrm{GW}$ in 2013 and 7 GW in 2014 [1]. In this context, specific emerging 'sun belt' markets such as those of Africa and South America, offer significant PV market potential in the medium term. For these emerging markets, a key opportunity is for the deployment of PV in a low or non-subsidy context informed by lessons learned from more mature markets. However, some strong barriers for PV deployment exist in these new markets, such as a high dependence on subsidized electricity prices together with socio-economic barriers, such as poverty incidence, income inequality, political and economic instability and highly volatile inflation and interest rates. For these reasons, an appropriate assessment of PV market risk, opportunities and competitiveness is necessary in order to inform policy, regulatory and business decisions. Therefore, a fundamental question is: how may PV competitiveness in emerging markets be evaluated?

Quantifying and defining competitiveness for PV energy is challenging; comparability between past analyses is poor, methodologies are still being developed [2][3], and issues exist around definition of boundaries and the input parameters adopted [4]. Furthermore, the intermittent and distributed character of PV generation raises several issues related to grid-connection and predictability of the 
solar resource [5]. Thus, the impacts of these characteristics on the competitiveness assessment of PV are not fully explicated.

Considering the position of South Africa (SA) as a leading economy in the continent, and the nascent development of its residential PV market, SA was chosen as the target country of this research. Based on a domestic case study, this work assesses the nature of PV energy competitiveness in the residential market, and proposes business models that could be used as examples for emerging PV markets elsewhere. Therefore, the objectives of this paper are:

- To evaluate the current status of residential solar PV energy competitiveness in SA.

- To analyze and compare the performance of proposed business models for the residential PV sector in SA in order to improve or achieve its competitiveness.

- To technically assess how the uncertainties and risks of the analysis affect the competitiveness evaluation model.

- To translate the analytical results into policy strategy for deployment of the PV residential sector in SA and emerging PV markets elsewhere.

\section{Market Assessment}

The South African energy market represents a case-study for similar emerging economies. Significant challenges exist related to combining the development of a more sustainable energy supply with economic growth and energy affordability. Furthermore, the energy industry is grappling with a limited capacity of supply, a carbon-intensive mix and a high dependency on coal.

Table 1 - South Africa electricity generation mix, 2013 [6]

\begin{tabular}{|c|c|c|c|c|c|}
\hline South Africa & Coal & Hydropower & Nuclear & Distillate & Total \\
\hline MW & 37,831 & 2,000 & 1,930 & 2,409 & 44,170 \\
\hline
\end{tabular}

The energy market in SA is dominated by the national state-owned utility company (Eskom). Due to the lack of planning in new generation investment in the context of a rapid increase in energy demand, capacity constraints are now emerging [7][8]. Installed capacity of about $45 \mathrm{GW}$ and a peak demand of $42.4 \mathrm{GW}$, represents a narrow reserve margin (Table 2). Eskom produces almost all of SA's electricity, and maintains a monopoly for ownership and operations of the national transmission system. Only about 2\% of SA's electricity is produced by independent power producers (IPP's). Eskom's current financial situation and market domination is having a negative market impact and disincentivises new investments. Thus, energy security in SA has been seriously compromised and the country faces power shortages and load sheddings [9].

Table 2 - South Africa 2013 generation statistics [6]

\begin{tabular}{|c|c|c|c|c|c|c|c|}
\hline \multirow{2}{*}{$\begin{array}{c}\text { South } \\
\text { Africa }\end{array}$} & $\begin{array}{c}\text { Installed } \\
\text { capacity }\end{array}$ & $\begin{array}{c}\text { Peak } \\
\text { demand }\end{array}$ & \multicolumn{2}{|c|}{ Available capacity } & $\begin{array}{c}\text { Energy } \\
\text { sent out }\end{array}$ & $\begin{array}{c}\text { Energy } \\
\text { sales }\end{array}$ & $\begin{array}{c}\text { Transmission } \\
\text { losses }\end{array}$ \\
\cline { 2 - 8 } (Eskom) & MW & MW & $\begin{array}{c}\text { \% peak } \\
\text { demand }\end{array}$ & GWh & GWh & $\%$ \\
\cline { 2 - 8 } & 44,170 & 42,416 & 41,074 & 87 & 237,430 & 224,446 & 3.3 \\
\hline
\end{tabular}


The resulting strategy is to increase electricity tariffs in an attempt to stem losses and gradually eliminate subsidies. The tariff increases have grown from a rate of 5.1\% in 2006/7 to a peak of $31.3 \%$ in 2009/10, well above inflation rates. These increasing electricity prices and concerns about energy security represent an opportunity for renewable energy (RE).

Figure 1 - Historical Eskom’s tariff increase vs. Consumer Price Index (CPI) [10]

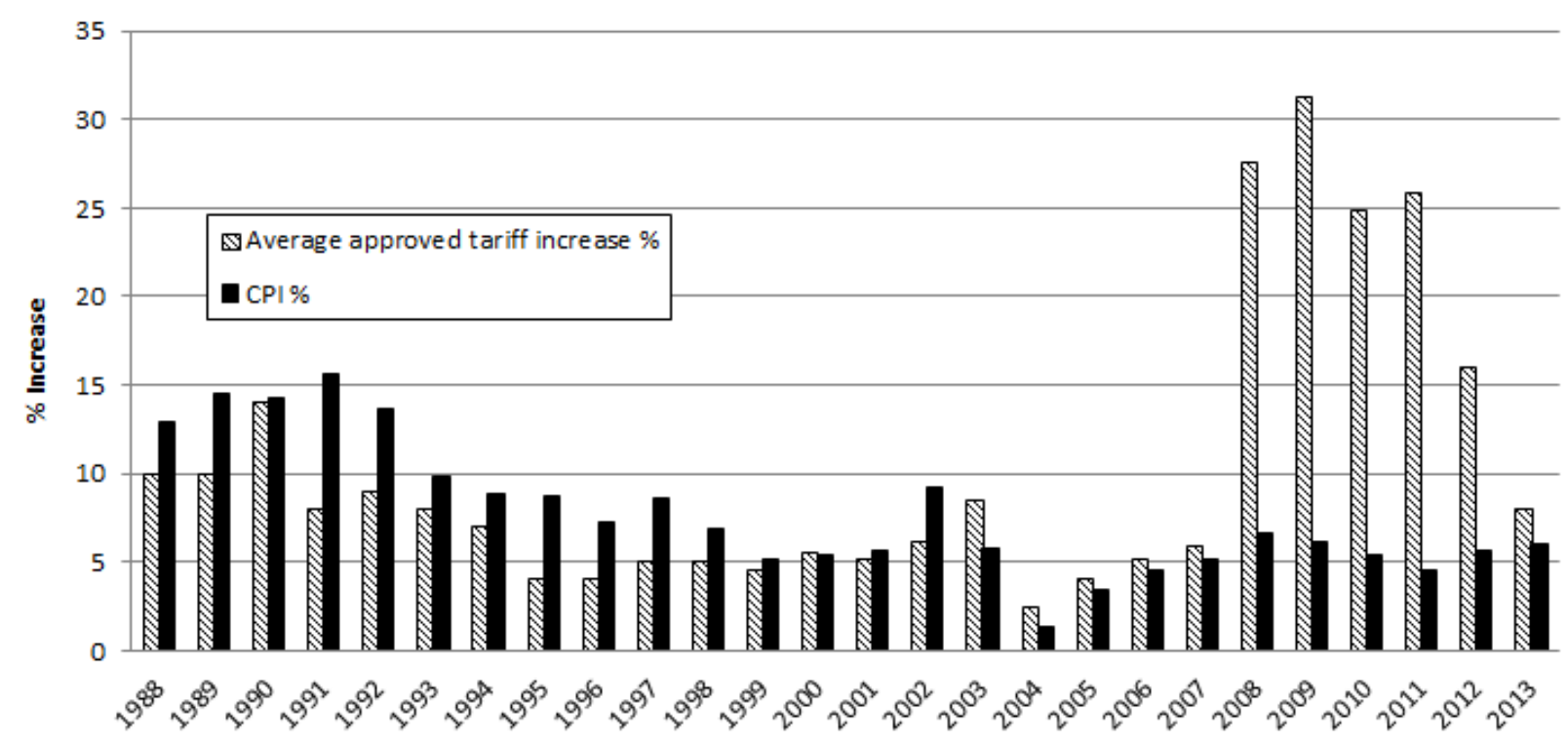

\subsection{Renewable Energy in South Africa}

In 2010, the Department of Energy of South Africa developed the Integrated Resource Plan [11] which proposed energy capacity expansion until 2030, showing a stronger commitment to the promotion of renewables.

Supporting mechanisms were created to stimulate an RE market, such as the Feed-in Tariff scheme in 2009 for utility-scale RE projects (REFIT). The REFIT process, however, was surrounded by high uncertainty regarding the procurement and licensing process and it was substituted two years later by the Renewable Energy Independent Power Procurement Program (REIPPP), which consists of a competitive bidding process. The REIPPP has been considered a very important case of success in supporting initial deployment of RE industry [12].

Table 3 - REIPPP average bid prices for solar photovoltaic projects [13]

\begin{tabular}{|c|c|c|c|c|}
\hline \multirow{2}{*}{ Bid } & $\begin{array}{c}\text { Window 1 } \\
\mathbf{2 0 1 1}\end{array}$ & $\begin{array}{c}\text { Window 2 } \\
\mathbf{2 0 1 2}\end{array}$ & $\begin{array}{c}\text { Window 3 } \\
\mathbf{2 0 1 3}\end{array}$ & $\begin{array}{c}\text { Window 4 } \\
\mathbf{2 0 1 5}\end{array}$ \\
\hline $\mathrm{R} / \mathrm{kWh}$ & 2.76 & 1.65 & 0.99 & 0.79 \\
\hline$€ / \mathrm{kWh}^{1}$ & 0.19 & 0.11 & 0.07 & 0.05 \\
\hline
\end{tabular}

Despite all the factors that act in favour of RE implementation, such as energy supply limitation, rising electricity charges and the rapid drop in PV technology prices, together with SA's significant solar resource, all these advantages have not yet been sufficient for PV to establish equally in all different market segments, namely large utility scale, commercial and residential. Expansion of the large-scale PV market through the REIPPP program has not been matched by the commercial and residential sectors.

\footnotetext{
${ }^{1}$ 14,4541 ZAR/EUR. 1 January 2014 to 17 November 2014.

https://www.ecb.europa.eu/stats/exchange/eurofxref/html/eurofxref-graph-zar.en.html
} 
The current motivation for households and small to medium size businesses to have rooftop PV systems is to be able to save on electricity bills, especially considering the yearly increase of prices. In most cities in SA, injection of electricity into the grid is not allowed. Since no bi-directional energy flow exists, residential and commercial systems are restricted in size, meaning that they should be optimized to ensure maximum self-consumption. However, the feasibility of installing domestic rooftop PV systems is compromised by the high initial capital cost.

Some municipalities have procedures to facilitate connection of small-scale generators to their networks, including the City of Cape Town, eThekwini, City of Johannesburg and Ekurhuleni. Most of these are exploring pilot net-metering programs to reduce their electricity expenses and motivate consumers to invest in PV systems. In addition, South African standards are being developed for small-scale distributed $\mathrm{PV}^{2}$. Other financial incentives were created such as Eskom's small scale RE program as part of the Standard Offer Program, but they were put on hold due to funding constrains [14].

\section{Defining competitiveness}

In the domestic context of this analysis, the concept of "socket parity" is adopted as one of the elements used to define PV competitiveness. Socket parity occurs when the energy generation technology's levelized cost of energy (LCOE) falls to or below the per-kilowatt-hour price charged by the utility. Once attained, it means customers can save money by generating electricity rather than purchasing it from their distributor [15]. LCOE can be defined as the cost of generation of one unit of energy $(€ / \mathrm{kWh})$, which means that when multiplied by the energy generated (Ei), it should be equal to the present value of the net costs $(\mathrm{Ci})$ of a particular technology, where $r$ is the discount rate, $\mathrm{n}$ is the total considered lifetime and $\mathrm{i}$ is each year of the calculation [4]:

\section{Figure 2 - Levelized cost of energy formula}

$$
\begin{aligned}
L C O E= & \frac{N P V C}{N P V E}, \text { where } N P V C_{(i, n)}=\sum_{n=1}^{n} \frac{C F_{P V ~ S Y S T E M, i}}{(1+r)^{n-1}} ; \\
& \text { and } N P V E_{(i, n)}=\sum_{n=1}^{n} \frac{E_{P V \text { SYSTEM, }}}{(1+r)^{n-1}}
\end{aligned}
$$

The net costs of the PV system should, when information is available, include any necessary payments for grid acces and related infrastructure. In order to have a more robust competitiveness assessment, this research considers investment risk as a key aspect of market development and PV competitiveness. This paper applies a quantitative analysis by using the Monte Carlo (MC) simulation of the risks associated with the financial performance of a PV system. Therefore, the definition of PV competitiveness applied here is when the risks associated with the PV system financial performance for a specific application are within the range of the risks the investor is willing to take.

\section{Methodology}

The assessment of PV competitiveness was via a case study approach of a single dwelling located in the city of Pretoria. The methodology followed four main steps, namely:

1. Prediction of PV system specific yield

2. Projection of PV system yield, load, and consumption profile over lifetime and system sizing

3. Socket parity evaluation and uncertainty analysis

\footnotetext{
${ }^{2}$ NRS097 series of specifications
} 
4. Competitiveness and risk assessment considering the cases, which will further be detailed:

- $\quad$ Base case (PV savings)

- $\quad$ Net-metering

- $\quad$ Net-billing

- Energy savings performance contract

\subsection{Data-sets}

Existing data-sets were used for environmental data (Meteonorm) and domestic load profiles (Eskom National Load Program) for a whole year. The location was chosen as Pretoria in the City of Tshwane Metropolitan Municipality where no incentive policy regarding domestic PV systems has been implemented as yet. Load data was obtained from a high income (average monthly income of 20,000 ZAR, approximately 1,400 €) household assuming that this class of electricity consumers is more likely to capitalize on domestic PV systems.

\subsection{Prediction of PV system specific yield}

Calculations are based on a rooftop grid-connected polycrystalline photovoltaic system. Irradiation and average ambient temperature hourly data were retrieved from the Meteonorm database for Pretoria $\left(25.445^{\circ} \mathrm{S}\right.$ and $\left.28.111^{\circ} \mathrm{E}\right)$. A typical inclination angle of $25^{\circ}$ was assumed for the household rooftop. The PV system specific yield was calculated according to the following model:

$$
\begin{gathered}
\text { PV System } \text { relative yield }\left(\frac{\mathrm{kWh}}{\mathrm{kWp}}\right)=\mathrm{G}\left(\frac{\mathrm{kWh}}{\mathrm{m}^{2}}\right) \times \mathrm{EF}_{\text {Inverter }} \times \mathrm{EF}_{\text {Array }} \\
\mathrm{G}=\text { Irradiation }\left(\frac{\mathrm{kWh}}{\mathrm{m}^{2}}\right) \quad \mathrm{EF}=\text { Efficiency factor }(\%)
\end{gathered}
$$

The efficiency factor (EF) of the PV system array was calculated as follows:

$$
\begin{gathered}
\mathrm{EF}_{\text {Array }}=0,95 \times \mathrm{EF}_{\mathrm{PV} \text { module }} \\
\text { When } \mathrm{G} \geq \mathrm{G}_{\text {Inverter start-up: }}: \\
\mathrm{EF}_{\mathrm{PV} \text { module }}=1+\mathrm{k}_{1} \times\left(\mathrm{T}_{\text {cell }}-\mathrm{T}_{\mathrm{STC}}\right) \\
\text { When } \mathrm{G}<\mathrm{G}_{\text {Inverter start-up }}: \\
\mathrm{EF}_{\mathrm{PV} \text { module }}=0
\end{gathered}
$$

Where:

$\mathrm{G}_{\text {Inv startup }}=$ Irradiation level above which the inverter operates $\left(\frac{\mathrm{kWh}}{\mathrm{m}^{2}}\right)$

$\mathrm{k}_{1}=\mathrm{PV}$ module temperature power coefficient $\left(\frac{\% \mathrm{~kW}}{{ }^{\circ} \mathrm{C}}\right)$ 
$\mathrm{T}_{\text {cell }}=$ Cell temperature $\left({ }^{\circ} \mathrm{C}\right)$

$\mathrm{T}_{\mathrm{STC}}=$ Temperature at Standard Test Conditions $\left({ }^{\circ} \mathrm{C}\right)$

The factor of 0.95 accounts for $5 \%$ of losses in mismatch and cabling [16]. The cell temperature ( $\left.\mathrm{T}_{\text {cell }}\right)$ was estimated based on irradiation and ambient temperature:

Where:

$$
\mathrm{T}_{\text {cell }}=\mathrm{T}_{\mathrm{amb}}+\mathrm{k}_{2} \times \mathrm{G}
$$

$\mathrm{T}_{\text {cell }}=$ Cell temperature $\left({ }^{\circ} \mathrm{C}\right)$

$\mathrm{T}_{\mathrm{amb}}=$ Ambient temperature $\left({ }^{\circ} \mathrm{C}\right)$

$\mathrm{k}_{2}=$ Conversion coefficient $\left({ }^{\circ} \mathrm{C} \frac{\mathrm{m}^{2}}{\mathrm{kWh}}\right)$

The inverter efficiency factor (EF) was defined as:

$$
\begin{aligned}
& \text { When } \mathrm{G}<\mathrm{G}_{\text {low efficiency }} \text { : } \\
& \qquad \mathrm{EF}_{\text {Inverter }}=93 \% \\
& \text { When } \mathrm{G}>\mathrm{G}_{\text {low efficiency }} \text { : } \\
& \mathrm{EF}_{\text {Inverter }}=97 \%
\end{aligned}
$$

\begin{tabular}{|c|c|c|c|}
\hline Parameter & Symbol & Value & Source \\
\hline Inverter start up irradiation & $\mathrm{G}_{\text {Inverter start-up }}$ & $70 \mathrm{~W} / \mathrm{m}^{2}$ & \multirow{4}{*}[16]{$[17][18][19]$} \\
\hline Inverter lower efficiency limit & $\mathrm{G}_{\text {low efficiency }}$ & $150 \mathrm{~W} / \mathrm{m}^{2}$ & \\
\hline Inverter lower efficiency & $\mathrm{EF}_{\text {Inverter }}$ & $93 \%$ & \\
\hline Inverter higher efficiency & $\mathrm{EF}_{\text {Inverter }}$ & $97 \%$ & \\
\hline Conversion coefficient $T_{\text {amb }}$ to $T_{\text {cell }}$ & $\mathrm{k}_{2}{ }^{3}$ & $0.04{ }^{\circ} \mathrm{Cm}^{2} / \mathrm{kWh}$ & {$[20][21][22][23]$} \\
\hline PV module temperature coefficient & $\mathrm{k}_{1}$ & $-0.004 \% \mathrm{~W} /{ }^{\circ} \mathrm{C}$ & {$[24][25][26][27][28]$} \\
\hline Efficiency factor for power array & $\mathrm{EF}_{\text {Array }}$ & $95 \%$ & {$[16]$} \\
\hline
\end{tabular}

Table 4 - Parameters used for the PV system specific yield calculation

4.3. Projection of PV system yield, load and consumption profile over lifetime and system sizing

Since currently there are no incentives in SA for electricity input to the grid, the residential PV system should be initially designed to maximise savings from the household electricity bill and therefore, maximize self-consumption over load.

In order to find the optimal share of self-consumption for this household, a simulation of PV generation together with concurrent consumption was performed for the whole lifetime of the system, on an hourly basis, considering a range of possible system sizes.

\footnotetext{
${ }^{3}$ This value is applicable to a rack-mounted module in the absence of wind.
} 
The PV system specific yield (kWh/kWp) was calculated as indicated previously in step 4.2. Then, for each possible system size $(\mathrm{kWp})$, the total PV system yield (kWh) was estimated for the first year of operation and for the following years it is considered to dregade at a rate of $0.8 \%$ a year.

The lifetime of the system was assumed to be equal to the lifetime of the module of 25 years based on its warranty offer. Data for the residential load was obtained from the Eskom National Load Program $^{4}$ for a high income household and considered to be constant through the whole period analyzed.

The simulation of the share of self-consumed PV generation, the quantity exported to the grid, as well as electricity imported from the grid was calculated via a comparison between the PV generation and household load hourly data for every year of the system’s lifetime.

When Load $_{1 \text { hour }}>$ Generation $_{1 \text { hour: }}$ :

$$
\begin{gathered}
\text { Selfconsumption }_{1 \text { hour }}=\text { Generation }_{1 \text { hour }} \\
\text { Feed in } \text { n }_{1 \text { hour }}=0
\end{gathered}
$$

When Load $_{1 \text { hour }}<$ Generation $_{1 \text { hour: }}$ :

$$
\begin{gathered}
\text { Selfconsumption }_{1 \text { hour }}=\text { Load }_{1 \text { hour }} \\
\text { Feed }- \text { in }_{1 \text { hour }}=\text { Generation }_{1 \text { hour }}-\text { Load }_{1 \text { hour }}
\end{gathered}
$$

Imports from the $\operatorname{grid}_{1 \text { hour }}=\operatorname{Load}_{1 \text { hour }}-$ Selfconsumption $_{1 \text { hour }}$

The results are shown in Figure 3 and indicate a maximum share of self-consumption over load of $45-47 \%$ and an optimal PV system between $3 \mathrm{~kW}$ and $6 \mathrm{kWp}$. Since the financial model results can vary quite significantly according to the system size choice, the simulation is performed initially with a $5 \mathrm{kWp}$ system which then is subjected to a sensitivity analysis.

\section{Figure 3 - Results of the simulation of share of self-consumption for different system sizes} (average for 25 years)

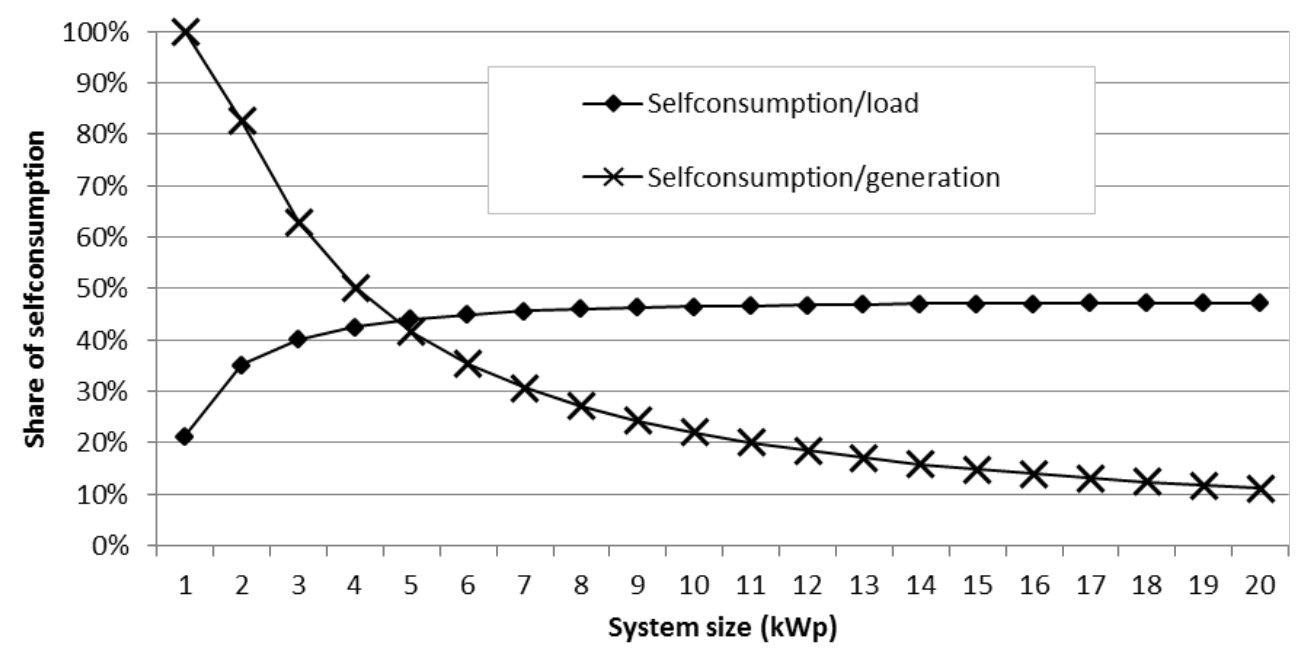

\footnotetext{
${ }^{4}$ Eskom RT\&D, 2014. Database of domestic loading data linked to tariff and demographic, climatic and spatial information as the results from the NRS 034 Domestic Load Research Project which involved collecting data for the last 18 years.
} 


\subsection{Discounted net cash flow}

The costs included in the model consist of the initial capital necessary to purchase all elements of a PV system: modules, inverter, balance of system (BOS) equipment and installation. The replacement of the inverter is considered every 10 years of operation, assumed based on its warranty offer.

Annual operation and maintenance (O\&M) costs were estimated as $1.5 \%$ of the initial costs. In order to better reflect reality of consumer prices fluctuation in SA, an inflation rate of $6 \%$ was applied to the yearly payments of the operation and maintenance services. The inflation rate was estimated based on the average of the last 20 years and on the trend for the past 4 years [29] [30].

In the current market context, income from a residential PV system is essentially derived from the avoided purchase of electricity through self-consumption. If business models such as net-metering or FITs are in place, revenues can be achieved through sales of electricity to the grid at rates established by the local utility. Considering current legislation in SA, no sales of electricity to the grid are allowed. Thus, net revenues are defined here for every year (i) as:

Savings from the electricity bill $=$ Electricity selfconsumed, $\mathrm{i} \times$ Price $_{\text {retail electricity, } \mathrm{i}}$

In order to properly estimate the savings obtained via a residential PV investment, it is important to project how retail electricity prices behave during the investment period of 25 years. According to Eskom and Pretoria's municipalities reports [31][32][33] tariffs are planned to increase at a rate of $8 \%$ in the next five years. Although there is an expectation of increases higher than $8 \%$ for the longer future, for conservative estimates, a constant escalation rate of $8 \%$ was assumed.

Figure 4 - Electricity tariff increase for Pretoria's municipality, City of Tshwane [34]

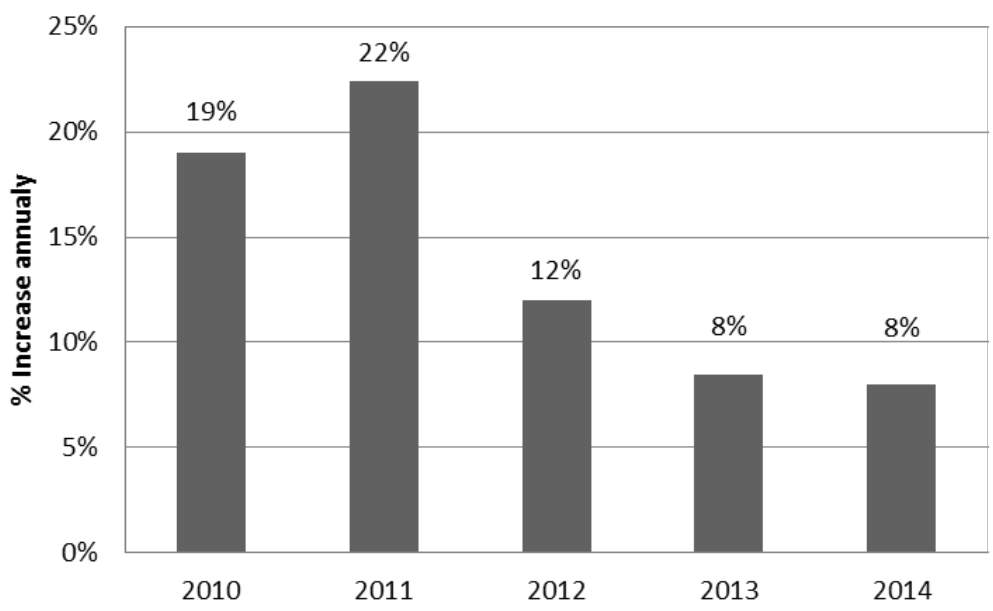

The total annual costs from the PV system are subtracted from the total annual revenues obtained, resulting in the yearly net cash flow of the project. The NPV is calculated where $C_{P V \text { SYSTEM,i }}$ is the net yearly cash flow, $n$ is the whole investment period (25 years), $r$ is the discount rate and $i$ is each year of the cash flow:

$$
N P V_{(i, n)}=\sum_{n=1}^{n} \frac{C F_{P V \text { SYSTEM, } i}}{(1+r)^{n-1}}
$$

For residential solar PV systems, risks include the variability in irradiation related to weather conditions, PV technical performance and market uncertainty regarding future policy on electricity rates and incentives, and module degradation rates. 
The discount rate takes as reference the cost of debt (which could be the interest rate of a loan), plus a share of risk, which is decided based on the type of investment. The average lending interest's rates, reported by the World Bank [29] and the South African Reserve Bank [30] have stabilized for the past years at around $9 \%$.

For individual investors, such as the owner of a PV system, the discount rate can be seen as the opportunity cost of this particular individual not investing the same amount of capital in projects of similar size which could bring the same or better return. In this case, the discount rate is represented by the required rate of return that this individual investor desires to obtain. Based on the interest's rates analysis, interviews with sector expert [35] and a literature review of household PV financial models in SA, a discount rate of $9 \%$ was considered.

Table 5 - Input data and sources

\begin{tabular}{|c|c|c|c|}
\hline Model Input Information & Value & Unit & Source \\
\hline System lifetime & 25 & years & \multirow{6}{*}{$\begin{array}{l}{[8][11][36]} \\
{[37][38][39]}\end{array}$} \\
\hline System capital cost & 1500 & $€ / \mathrm{kWp}$ & \\
\hline System O\&M cost (\% of capital cost) & $1.5 \%$ & a year & \\
\hline Discount rate (WACC) & $9 \%$ & a year & \\
\hline System size & 5 & $\mathrm{kWp}$ & \\
\hline Degradation coefficient & $0.80 \%$ & a year & \\
\hline Retail electricity price & 0.10 & $€ / \mathrm{kWh}$ & [32] \\
\hline Export tariff & 0.00 & $€ / \mathrm{kWh}$ & [40] \\
\hline Retail electricity price escalation & $8 \%$ & a year & {$[31][32][33]$} \\
\hline Exchange rate & 14.45 & ZAR/EUR & [41] \\
\hline Inflation & $6 \%$ & a year & [29] [30][42] \\
\hline
\end{tabular}

\subsection{Risk assessment}

In a study of this kind, implicit in every model input parameter are levels of uncertainty which aggregate during the analysis and compromise the validity of the outputs. Thus, before investing in a new project, it is necessary to understand the range of possible outputs considering the potential variation in the input parameters. Variability can be related to external circumstances, such as market stability and weather conditions, or also in the assumptions adopted, such as system lifetime and the PV degradation coefficient. Therefore, it is fundamentally important to perform a risk analysis to identify which assumptions and input parameters most impact the primary outputs. To this end, a risk analysis was implemented via a Monte Carlo simulation using 5,000 iterations.

For every input variable, a range of possible values and a probability distribution are defined in such a way that best express its behaviour in real life (Table 6). As an example, for the entry data "Increase of retail electricity price" a range of possible values was defined as the minimum being $0 \%$ (no increase at all) and the maximum being $14 \%$. The probability distribution was chosen as a triangular distribution, meaning that $90 \%$ of the occurrences will be at least between $2-12 \%$, which reflects the difficulty in forecasting future tariff trajectories. 
Table 6 - Probability distributions for each input variable used in the Monte Carlo simulation

\begin{tabular}{|c|c|c|c|c|c|c|}
\hline Input Variable & $\begin{array}{l}\text { Probability } \\
\text { Distribution }\end{array}$ & $\begin{array}{c}\text { Min } \\
\text { value }\end{array}$ & $\begin{array}{l}\text { Input } \\
\text { Value }\end{array}$ & $\begin{array}{c}\text { Max } \\
\text { Value }\end{array}$ & $\begin{array}{c}5 \% \\
\text { lower limit }\end{array}$ & $\begin{array}{c}95 \% \\
\text { upper limit }\end{array}$ \\
\hline $\begin{array}{c}\text { Increase of } \\
\text { retail electricity } \\
\text { price }\end{array}$ & & $0 \%$ & $8 \%$ & $14 \%$ & $2 \%$ & $12 \%$ \\
\hline System size & & $\begin{array}{c}4 \\
k W p\end{array}$ & $\begin{array}{c}5 \\
\mathrm{kWp}\end{array}$ & $\begin{array}{c}10 \\
\mathrm{kWp}\end{array}$ & $\begin{array}{c}4.5 \\
\mathrm{kWp}\end{array}$ & $\begin{array}{c}8.8 \\
\mathrm{kWp}\end{array}$ \\
\hline System cost & & $-\infty$ & $\begin{array}{l}1,500 \\
€ / \mathrm{kWp}\end{array}$ & $+\infty$ & $\begin{array}{l}1,006 \\
€ / \mathrm{kWp}\end{array}$ & $\begin{array}{c}1,993 \\
€ / \mathrm{kWp}\end{array}$ \\
\hline $\begin{array}{c}\text { Inverter } \\
\text { replacement } \\
\text { cost }\end{array}$ & & $-\infty$ & $\begin{array}{c}314 \\
€ / \mathrm{kWp}\end{array}$ & $+\infty$ & $\begin{array}{c}212 \\
€ / \mathrm{kWp}\end{array}$ & $\begin{array}{c}416 \\
€ / \mathrm{kWp}\end{array}$ \\
\hline $\begin{array}{c}\text { O\&M } \\
\text { (percentage of } \\
\text { system cost) } \\
\end{array}$ & & $-\infty$ & $\begin{array}{l}1.5 \% \\
\text { year }\end{array}$ & $+\infty$ & $\begin{array}{l}1.3 \% \\
\text { year }\end{array}$ & $\begin{array}{l}1.7 \% \\
\text { year }\end{array}$ \\
\hline Inflation & & $\begin{array}{l}3.0 \% \\
\text { year }\end{array}$ & $\begin{array}{l}6.0 \% \\
\text { year }\end{array}$ & $\begin{array}{c}9.0 \% \\
\text { year }\end{array}$ & $\begin{array}{l}3.9 \% \\
\text { year }\end{array}$ & $\begin{array}{l}8.1 \% \\
\text { year }\end{array}$ \\
\hline Discount rate & & $5 \%$ & $9 \%$ & $14 \%$ & $6 \%$ & $12 \%$ \\
\hline $\begin{array}{c}\text { Degradation } \\
\text { coefficient }\end{array}$ & & $\begin{array}{c}0.50 \% \\
\text { year }\end{array}$ & $\begin{array}{c}0.8 \% \\
\text { year }\end{array}$ & $\begin{array}{c}1.00 \% \\
\text { year }\end{array}$ & $\begin{array}{c}0.59 \% \\
\text { year }\end{array}$ & $\begin{array}{c}0.93 \% \\
\text { year }\end{array}$ \\
\hline $\begin{array}{c}\text { PV system } \\
\text { yearly specific } \\
\text { yield }\end{array}$ & & $-\infty$ & $\begin{array}{c}1,884 \\
\mathrm{kWh} / \mathrm{kWp}\end{array}$ & $+\infty$ & $\begin{array}{c}1,390 \\
\mathrm{kWh} / \mathrm{kWp}\end{array}$ & $\begin{array}{c}2,377 \\
\mathrm{kWh} / \mathrm{kWp}\end{array}$ \\
\hline
\end{tabular}

The simulation runs 5,000 repetitions of the calculation using random combinations of the possible entry values, based on the pre-defined ranges and probability distributions. As a result, it gives the correspondent range of outputs (in this case LCOE, NPV, IRR) associated to its number of occurrences. Therefore, it is possible to extract a mean value, which represents the most likely outcome given the variability of each input data. The mean is the one associated to the highest number of occurrences.

\section{Socket parity}

In the scope of this case study, socket parity is defined as the comparison of the LCOE costs of the residential PV system with the electricity tariffs paid by the household to the local electricity distributor. LCOE was calculated and compared to the current retail electricity price. LCOE was also calculated annually considering the yearly projected energy yield and costs. Mathematically, the LCOE is the present value of the annual LCOE.

Initially, the results indicate that from the first year of investment, LCOE is equal to or less than the retail tariff, and thus the attainment of socket parity is indicated (Figure 5). The annual LCOE is apparently lower than electricity prices throughout the lifetime of the project, therefore it seems that this proposed PV residential system is potentially competitive with the retail electricity supply, thus 
justifying the household owner to proceed with its installation. However, a complete analysis should evaluate the level of uncertainties in the LCOE calculation.

Figure 5 - Results of the socket parity analysis for a domestic 5kWp system

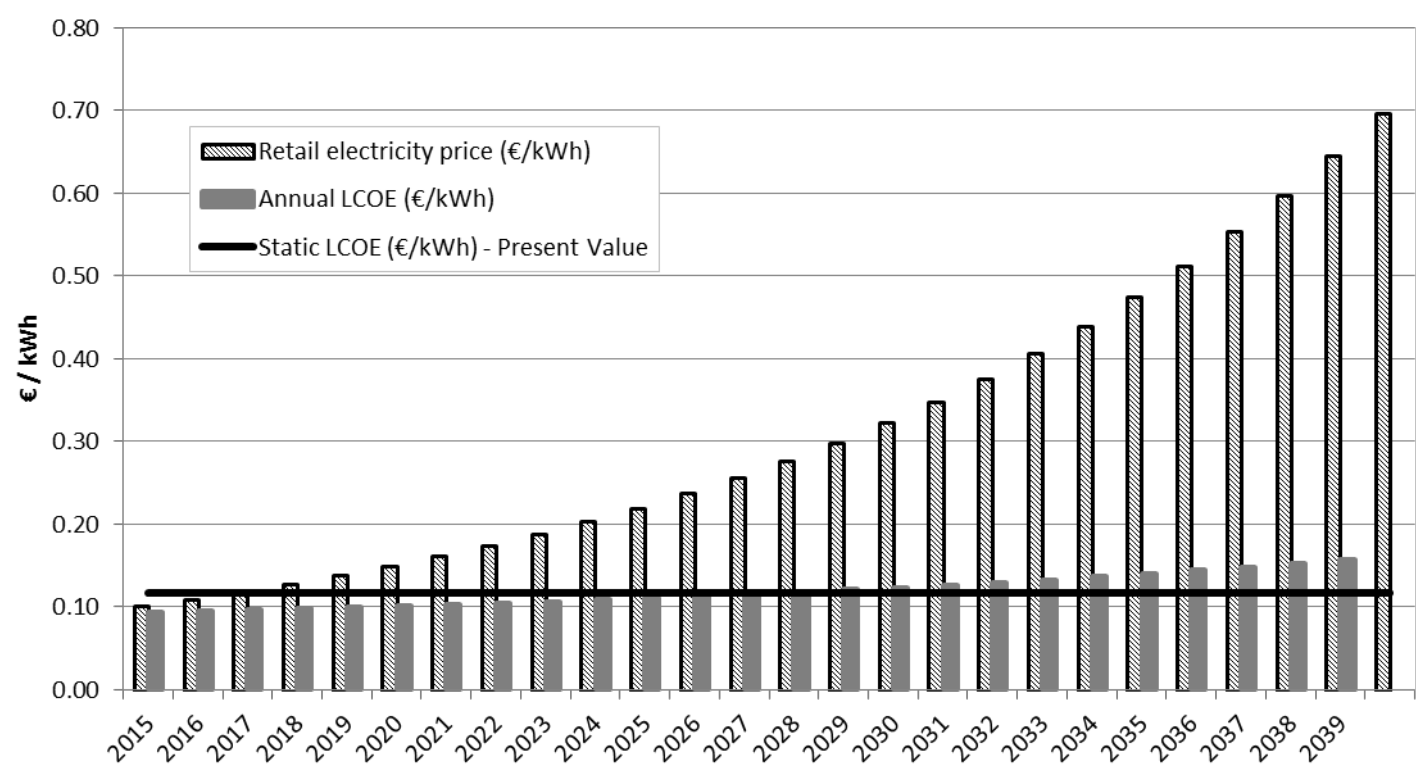

The MC simulation resulted in a range of values of LCOE, with the mean equal to $0.12 € / \mathrm{kWh}$ (Figure 6a). This is higher than the current retail electricity tariff in Pretoria for households of similar levels of electricity consumption (approximately $0.10 € / \mathrm{kWh}$ for a monthly consumption of $750 \mathrm{kWh})$. Thus, depending on assumptions relating to the parameters analyzed, a significant degree of uncertainty exits with regards achievement of socket parity. Variations in parameters such as installed PV system cost, system yield and the discount rate all have a significant impact on LCOE (Figure 6a). This illustrates the subjectivity of the analysis to these assumptions.

Figure 6 - Results of the LCOE Monte Carlo simulation

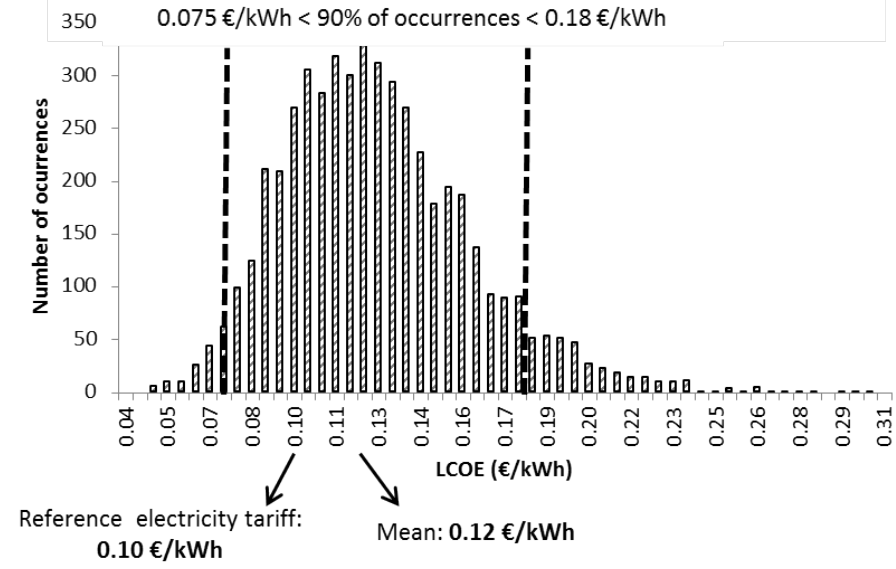

a) Histogramme for LCOE

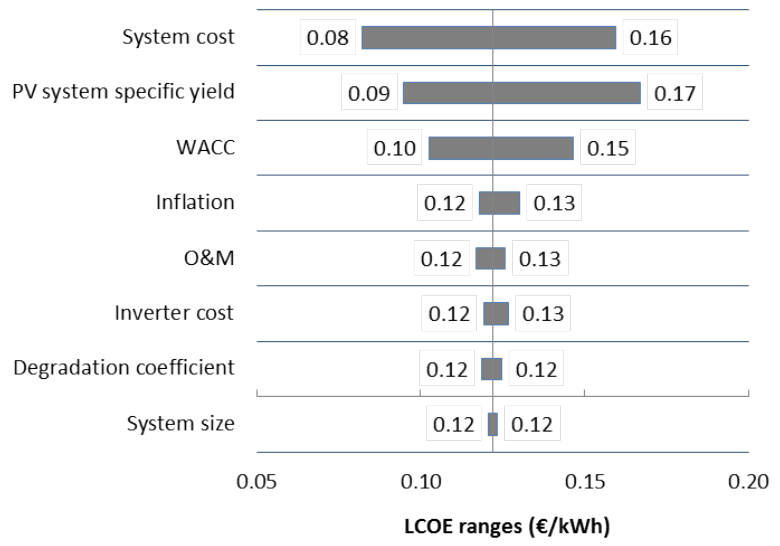

b) Sensitivity analysis for LCOE

\section{Use-case Discounted Cash Flow Analyses}

For the residential PV system in Pretoria a financial model was constructed in order to carry out a discounted net cash flow analysis for four cases:

- Case 1: Savings from PV system (base case) 
- $\quad$ Case 2: PV system with net-metering (NM) (proposed)

- Case 3: PV system with net-billing (NB) (proposed)

- $\quad$ Case 4: PV system with energy savings performance contract (ESPC) (proposed)

\subsection{Case 1: Savings from PV system (base case)}

Case 1 represents the current market status for the city of Pretoria. Benefits from a PV system are represented by the potential savings achieved in the electricity bills (i.e. via PV energy selfconsumption). The direct results of the financial model can be seen in Figure 7. The outputs results indicate that the residential 5kWp PV system proposed in this case study may not be competitive. Payback is in approximate 16 years and the negative NPV suggests a loss in capital opportunity and therefore the project has high chances of not being profitable.

Figure 7 - Cumulative cash flow of 5kWp PV system in Pretoria, SA

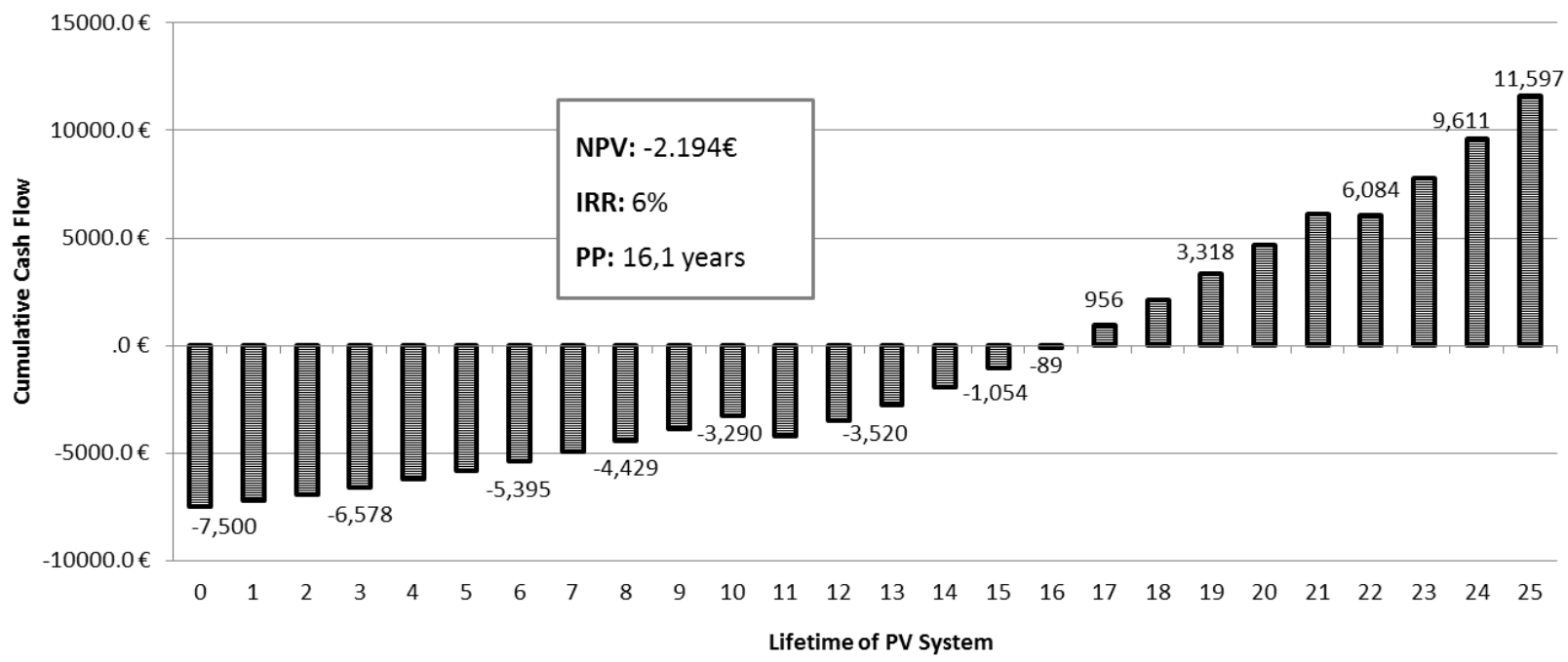

The MC simulation resulted in a mean NPV of $-4,753.40 €$ (Figure $8 \mathrm{a}$ ) and a mean IRR of $3.3 \%$ (Figure 8b). The high standard deviation and the negative mean NPV value indicate a high probability that the project will not be profitable, and thus this case study consists of a high risk investment.

With regards to the sensitivity of the NPV and IRR analysis to each input parameter (Figure 8c and Figure 8d) it is possible to observe which variables represent the most significant sources of investment risk. For both NPV and IRR, assumptions related to the increase in electricity tariffs result in the most impact, and thus future electricity tariff uncertainty represents a significant investment risk for rooftop PV systems in SA. 


\section{Figure 8 - Results of Monte Carlo for NPV and IRR}

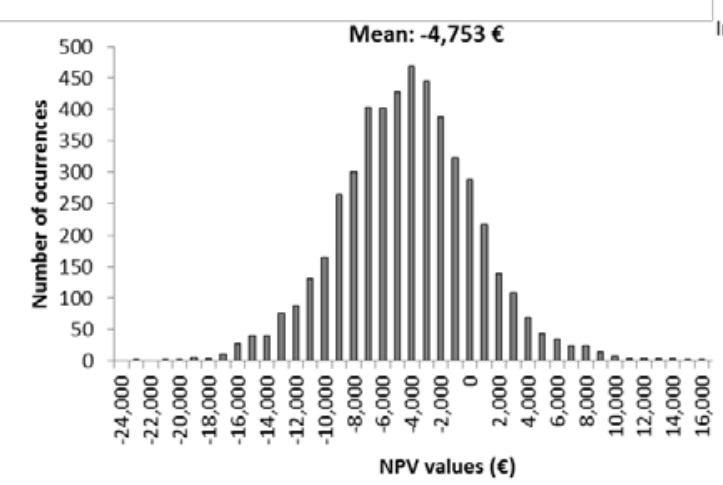

a) Histogramme for NPV

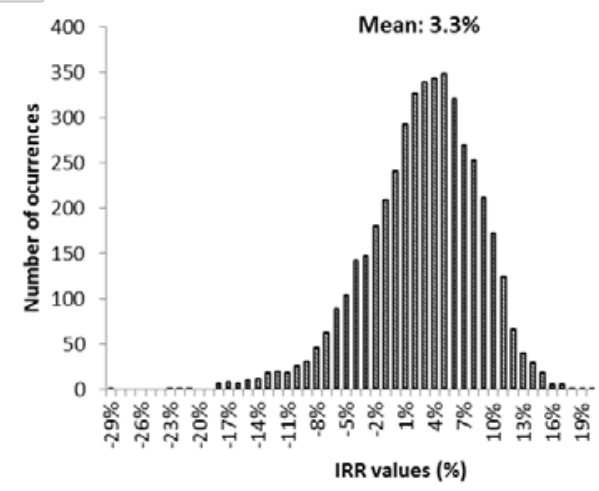

b) Histogramme for IRR

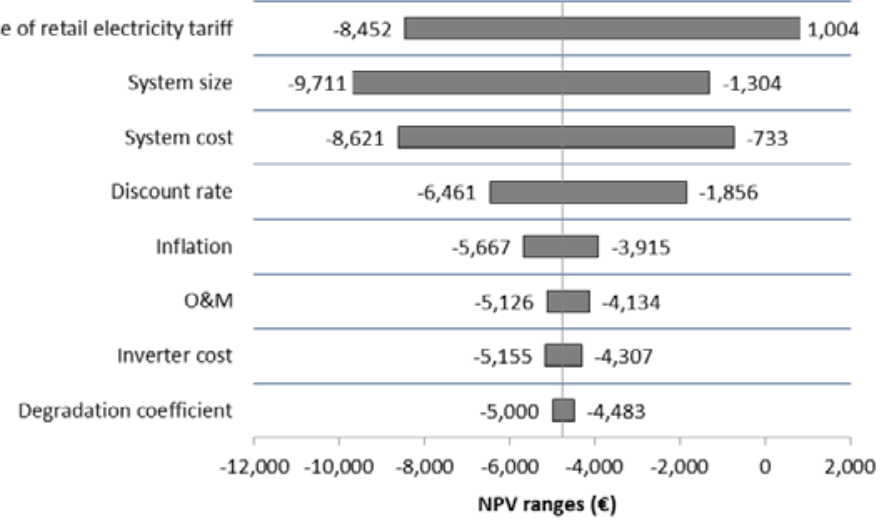

c) Sensitivity analysis for NPV

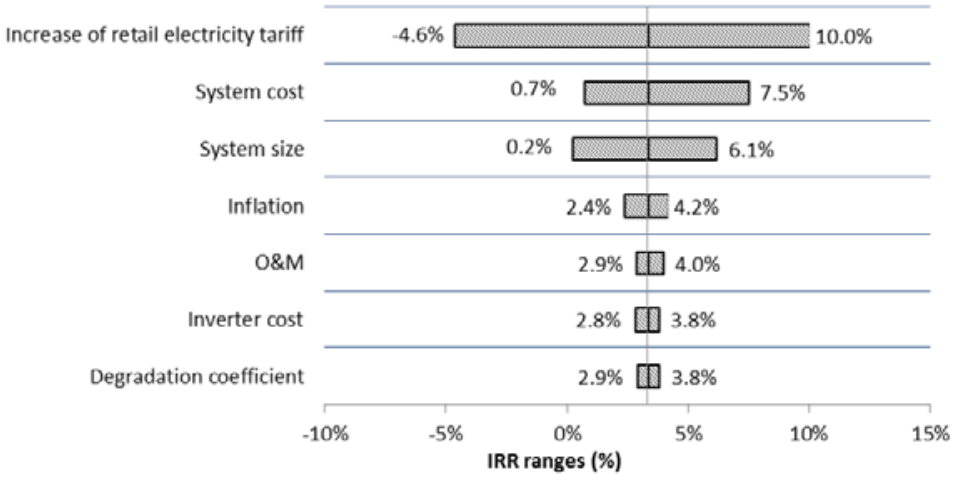

d) Sensitivity analysis for IRR

Discount rate also has a considerable impact on NPV, and will vary according to each individual investor's priorities. Therefore, it should be carefully understood and applied.

Another significantly sensitive parameter is the system size, and illustrates that proper sizing of the system is necessary, given that in SA currently no schemes for gross generation or recompense for grid export of surplus electricity are currently in place. Since this is a factor for which the householder or installer has complete control of, it is possible to size the system in order to maximise self-consumption and reduce the proportion of grid export, assuming no local electricity storage capability, which is beyond the scope of this study. Fixing other variables at their initial values, Figure 9 shows the effect of system size on profitability. 
Figure 9 - Sensitivity analysis for NPV and IRR considering different system sizes

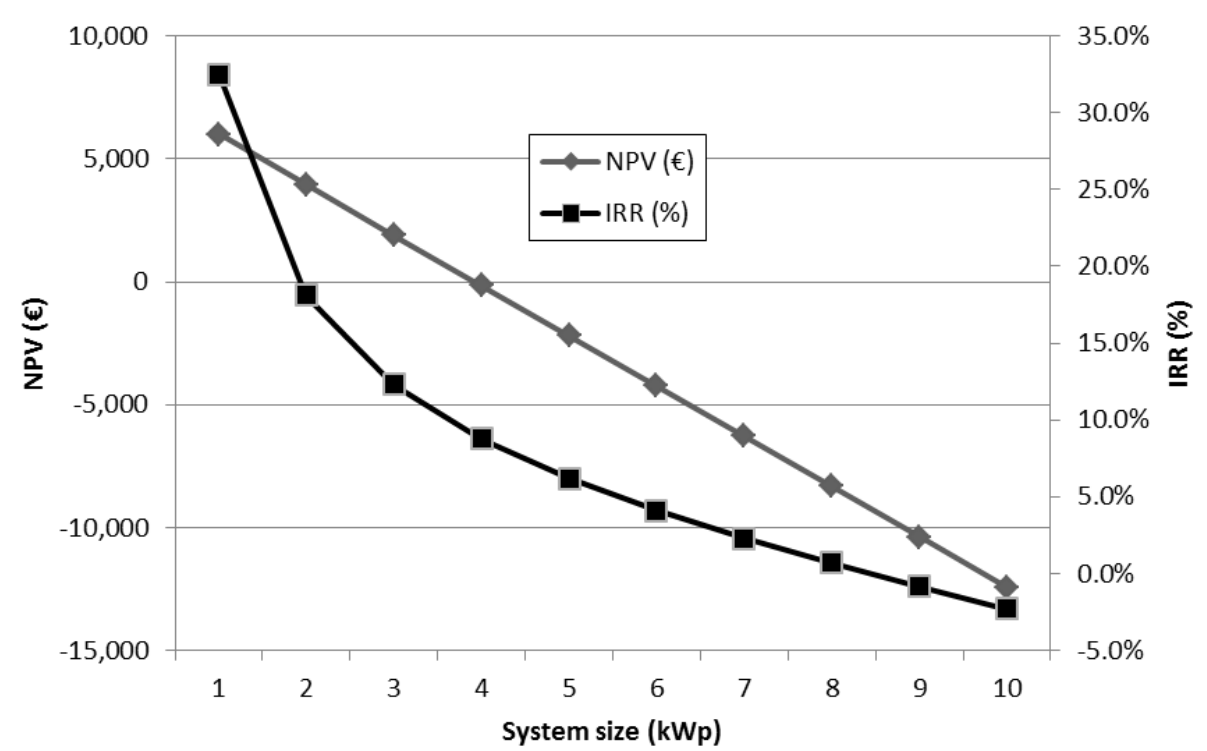

NPV and IRR decrease considerably with increasing system size. Therefore, for this case, smaller installed systems can contribute to improve profitability considering the current status of support policy of residential PV systems in Pretoria.

The main conclusion for this case is that PV is not yet a competitive source of energy for the household considered, given the current unfavorable conditions in SA for connecting PV into the distribution grid. The mismatch between electrical load and PV generation profile creates a situation where surplus of electricity during peak generation and low demand is not compensated. The economic savings are limited to the share of self-consumption from the PV system and to the uncertainties associated to electricity tariffs increases. Therefore, for this case, there is not a sufficient apparent return to stimulate investment in the domestic PV sector in SA. In light of these results, the next sections evaluate potential business models that could be put in place for residential PV systems in order to minimize investment risks and improve competitiveness.

\subsection{Case 2: Net-metering}

Net-metering (NM) is a practice by which owners of distributed generation units may obtain value for the electricity they add to the grid. Under the NM scheme considered for this case study, whenever the PV generation of the household exceeds its electricity consumption, exported electricity is valued at the full retail tariff limited to the total household consumption. This is consistent with the recently implemented pilot NM schemes in Cape Town and Nelson Mandela Bay municipalities [43][44].

\subsection{Case 3: Net-billing}

The net-billing (NB) case all the surplus of PV generated electricity, which means the precise amount of PV electricity fed into the grid at times when PV generation exceeds electricity consumption, is purchased at a set price by the local distributor. The amounts of electricity generated and consumed are compared constantly, and the utility purchases the difference when the generation is larger than consumption.

The difference between the NB and the NM case is that for NB remuneration occurs for all surplus of electricity fed into the grid at a fixed export tariff. For NM the electricity injected into the grid accounts for credits in the electricity bill after the billing period (monthly) and does not exceed the total household consumption. 
This option allows local distributors to define the export tariff for the electricity injected into the grid by the PV generators, which does not necessarily corresponds to the distribution retail prices as in the NM case.

Profitability from the PV system thus depends on the defined export price of selling electricity to the grid. The calculations of NPV and IRR for this case were based on the minimum tariff necessary for NPV to be zero, which means the system will pay for itself considering self-consumption savings and revenues for the sales of the net electricity exported.

The minimum export tariff in order for NPV to be zero, was found to be $0.04 € / \mathrm{kWh}$. This represents 39\% of the current electricity retail price charged in Pretoria for households consuming $750 \mathrm{kWh} /$ month, such as the one analyzed in this case study. As a comparison, the breakdown of the domestic supply cost by Eskom [45] can be seen in Figure 10 suggesting that such an export tariff would be less than the energy component of the current domestic tariff. Thus, this is a preliminary assessment and the definition of the export price is a process that should consider the detailed cost component of electricity charges in order to avoid creating burden to public finances and in the electricity tariffs for all consumers. At the same time, a price that is too low might not be attractive to potential PV investors.

\section{Figure 10 - Domestic electricity cost of supply per customer by Eskom}

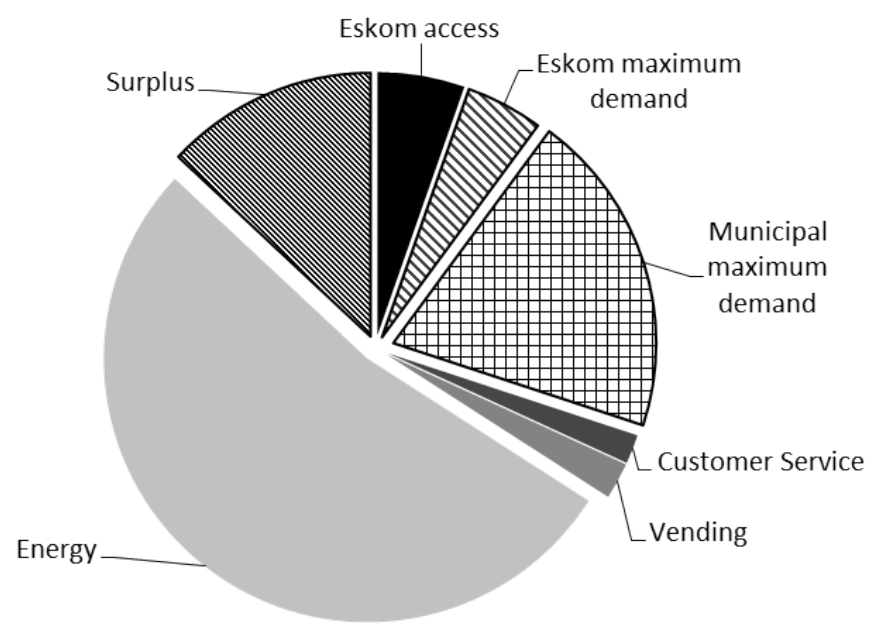

\subsection{Case 4: Electricity savings performance contract}

The fourth case analyzed in this study consists of a business model that aims to shift the risks associated to the initial capital invested by the householder to a third party represented by an Energy Services Company (ESCO), which could be owned by the utility, the municipality, a private company or by a joint venture vehicle co-owned by various stakeholders, potentially also including the householder. In the model proposed, the ESCO capitalizes on the PV system and retains ownership and responsibility for the PV system. The ESCO offers savings related to PV electricity self-use as a service to the householder. Alternatively, the ESCO could offer a competitive energy tariff for all or part of household electricity consumption that effectively shares the benefits accrued from PV-derived revenues. This arrangement fits well with electricity distributors' core competencies of asset ownership and operation, potentially generating the greatest overall value for them [46][47][48].

The contract between the ESCO and the customer establishes minimum energy savings for the customers and a share of payment from the customer for the services. In this case, assuming a minimum of $40 \%$ self-consumption, the savings agreement is assumed to be $30 \%$ of total electricity 
costs, and then the household pays for $10 \%$ of that share to the ESCO. Since the ESCO sells the rest of the generated electricity at a retail tariff, revenues are accrued for both parties. Therefore, for this case, results can be analyzed from the perspective of the householder (Case 4.1), who benefits from the services provided by the ESCO as well as under the ESCO perspective (Case 4.2).

\subsection{Comparison of business models}

The MC simulation results for NPV of all business cases are presented in Table 7.

Table 7 - Results for MC simulation for NPV (€) for all business cases

\begin{tabular}{|c|l|c|c|c|c|}
\hline Number & \multicolumn{1}{|c|}{ Case } & $\mathbf{5 \% ~ l i m i t}$ & Mean & $\mathbf{9 5 \% ~ l i m i t ~}$ & $\begin{array}{c}\text { Standard } \\
\text { Deviation }\end{array}$ \\
\hline 1 & Base case (no support) & $-12,557.14$ & $-4,753.00$ & $2,884.35$ & $4,898.44$ \\
\hline 2 & Net-metering & $-5,149.00$ & $4,858.68$ & $18,633.19$ & $7,282.07$ \\
\hline 3 & Net-billing & $-8,497.15$ & $-1,619.11$ & $5,915.37$ & $4,494.22$ \\
\hline 4.1 & $\begin{array}{l}\text { Energy savings performance } \\
\text { contract (household) }\end{array}$ & $2,429.87$ & $4,962.03$ & $9,104.09$ & $2,152.37$ \\
\hline 4.2 & $\begin{array}{l}\text { Energy savings performance } \\
\text { contract (ESCO) }\end{array}$ & $-2,934.03$ & $8,771.83$ & $27,713.33$ & $10,084.51$ \\
\hline
\end{tabular}

The results of the discounted cash flow analysis indicate that the base case presents a high probability of unprofitability given the assumptions used in the analysis. In contrast, the NM case presents a higher probability of a positive NPV, albeit with a large range of NPV (SD = €7.2K), indicating that the project is still subject to a degree of inherent uncertainty and resulting investment risk, although less than the base case of PV with no support scheme.

The NM case is also the case with higher projected mean IRR for the household of almost $13 \%$ (Table 8). That is significant for policy makers, because an IRR which is too attractive could create a situation of over-demand which could result in supply-side market constraints, or undesirable impacts on the electrical distribution network due to excessive penetration of PV.

Nevertheless, this analysis illustrates the potential for NB schemes using for example variable tariffs according to time of import/export to the grid in order to incentive beneficial import/export regimes and to pride a service to the local distribution network operator. It could also represent a low-cost mean for distributors to absorb higher penetrations of PV residential systems without the need for extra infrastructural investment and therefore fewer burdens to public and end-users finances. 
Table 8 - Results for MC simulation for IRR for all business cases

\begin{tabular}{|c|l|c|c|c|c|}
\hline Number & \multicolumn{1}{|c|}{ Case } & $\mathbf{5 \% ~ l i m i t ~}$ & Mean & $\mathbf{9 5 \%}$ limit & $\begin{array}{c}\text { Standard } \\
\text { Deviation }\end{array}$ \\
\hline 1 & Base case (no support) & $-6.5 \%$ & $3.3 \%$ & $11.5 \%$ & $5.7 \%$ \\
\hline 2 & Net-metering & $3.9 \%$ & $12.9 \%$ & $21.6 \%$ & $5.5 \%$ \\
\hline 3 & Net-billing & $-0.9 \%$ & $6.9 \%$ & $14.4 \%$ & $4.7 \%$ \\
\hline 4.1 & $\begin{array}{l}\text { Energy savings performance } \\
\text { contract (customer) }\end{array}$ & $\mathrm{n} / \mathrm{a}$ & $\mathrm{n} / \mathrm{a}$ & $\mathrm{n} / \mathrm{a}$ & $\mathrm{n} / \mathrm{a}$ \\
\hline 4.2 & $\begin{array}{l}\text { Energy savings performance } \\
\text { contract (ESCO) }\end{array}$ & $5.7 \%$ & $15.3 \%$ & $22.9 \%$ & $5.7 \%$ \\
\hline
\end{tabular}

The simulation for the NB case results in a probability of lower financial returns than the NM case; however NB still represents a more positive risk outlook than the base case (Case 1). For this reason, the NB business case could be a possible solution in order to implement an electricity exchange model, similar to NM, which represents more moderate return to the system owner with more control of revenues and expenses for the distributor.

Of note is that these three cases have significant distributions of NPV and IRR values, including a $5 \%$ probability of a negative outcome for NB. This is due to a high dependency on external factors, principally the uncertain dynamic increase in retail electricity tariffs, together with future export tariffs.

A sensitivity analysis of NPV for the NB case (Figure 11) indicates that variations in the export tariff results in a minimal effect on NPV; it is the increase in retail electricity tariffs that determine the extent of profitability. The results show that the electricity tariff escalation rate determines the largest influence on the project's financial feasibility.

Figure 11 - Sensitivity analysis for NPV for Case 3: Net-billing

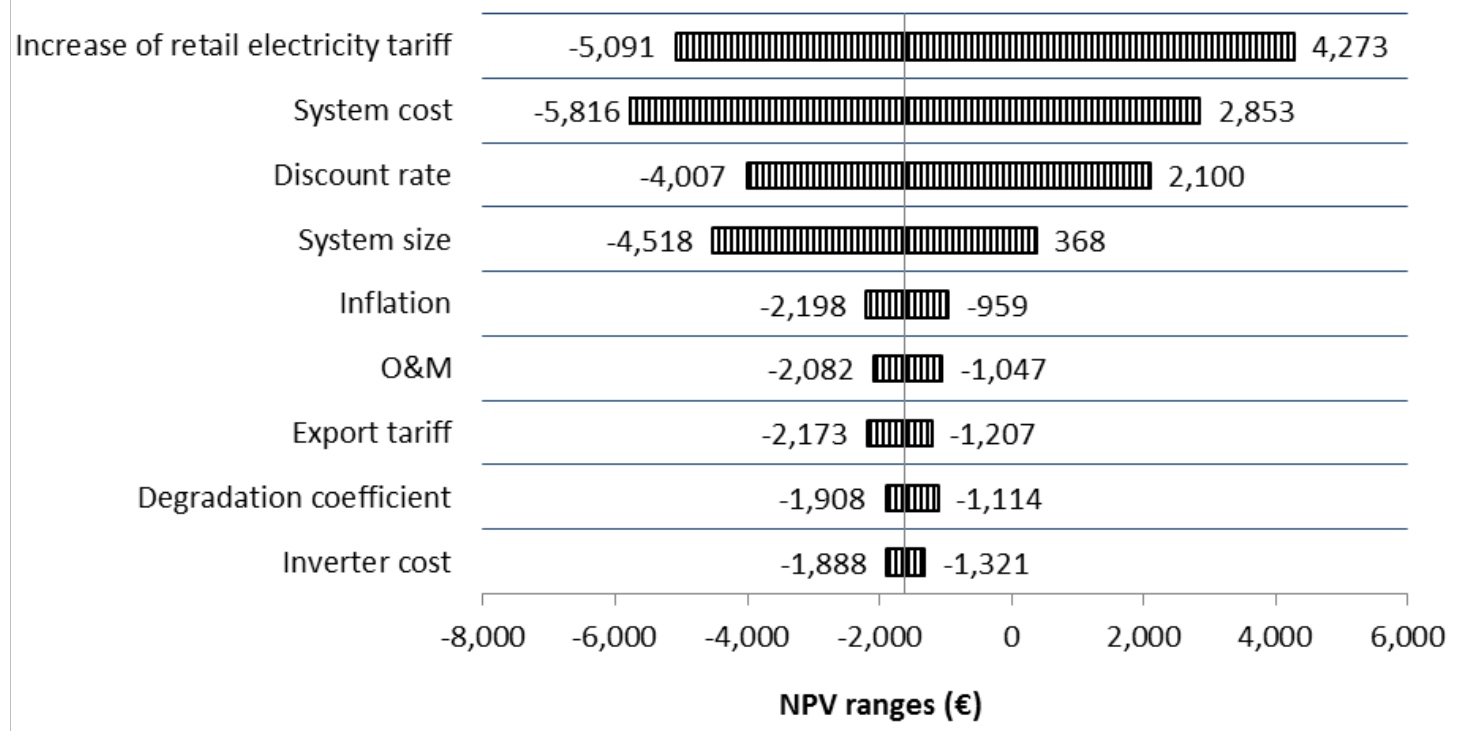

For the current study, the electricity export tariff is assumed to be the calculated value of 0.04 $€ / \mathrm{kWh}$, with a range following a normal distribution as presented in Table 9.

\footnotetext{
${ }^{5}$ Since there is no capital invested from the household IRR is not applicable for this case.
} 
Table 9 - Probability distribution for electricity export tariff used in the NB case

\begin{tabular}{|c|c|c|c|c|c|c|}
\hline $\begin{array}{c}\text { Input } \\
\text { Variable }\end{array}$ & $\begin{array}{c}\text { Probability } \\
\text { Distribution }\end{array}$ & Minimum & $\begin{array}{c}\text { Input } \\
\text { value }\end{array}$ & Maximum & $\begin{array}{c}\mathbf{5 \%} \\
\text { lower } \\
\text { limit }\end{array}$ & $\begin{array}{c}\mathbf{9 5 \%} \\
\text { upper } \\
\text { limit }\end{array}$ \\
\hline $\begin{array}{c}\text { Electricity } \\
\text { export tariff }\end{array}$ & \begin{tabular}{l}
0,028 \\
\hline
\end{tabular} & 0.024 & 0.038 & 0.053 & 0.031 & 0.044 \\
\hline
\end{tabular}

Finally, the ESPC case results in potential electricity bill savings for the household as part of an energy service provided by the ESCO, whilst reducing risk from the householder's perspective. For the customer, risks are less dependent on external factors and profitability is mainly dictated by the contract guarantees of the services provided by the ESCO. Since the customer does not retain ownership of the PV asset, capitalization risk is not assumed. All projected NPV values are positive for this case. Furthermore, in this business model, the customer is protected from possible system failures and changes in electricity price policy.

From the ESCO perspective, Table 7 shows that the ESCO, who owns and control the system now assumes a greater share of risks. However, the transfer of capitalization risks from the household to the ESCO also implies that returns can be significant higher for the ESCO. While the mean NPV for the household is of $4,962.00 €$, that for the ESCO is significantly greater $(8,772.00 €)$, albeit involving a higher degree of risk.

Figure 12 summarizes the MC simulation results for all cases. Each business model is represented in a ranking from the higher to the lower risk.

Figure 12 - Ranges ${ }^{6}$ for NPV after MC simulation for each of the business models

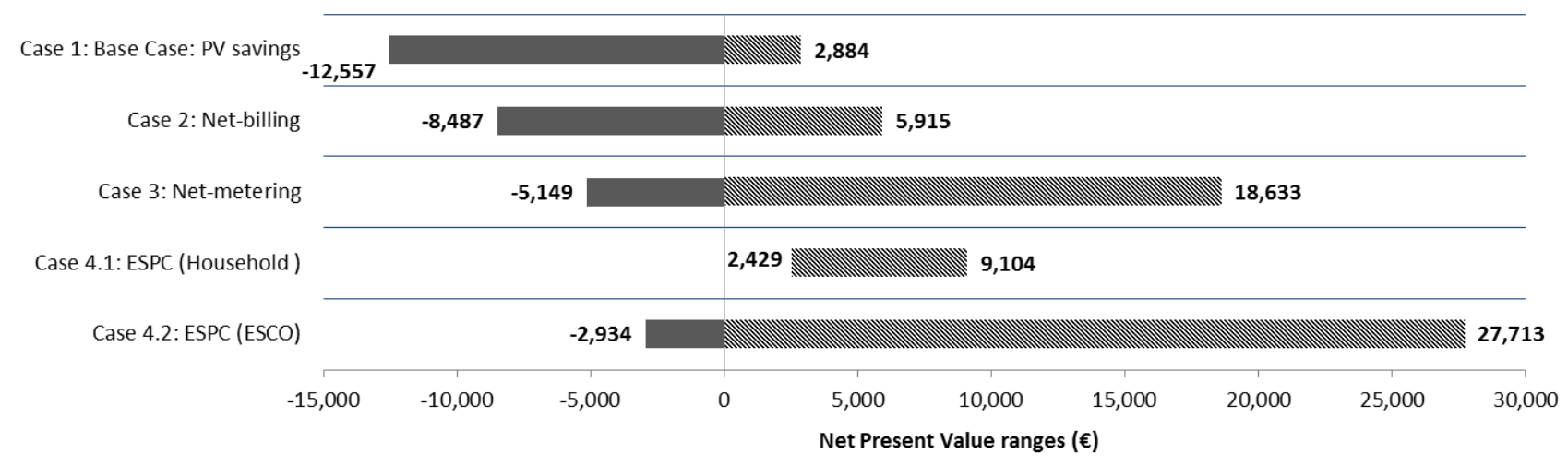

A key aspect associated with all business models is that they can benefit the local distributor as well as the household, thus supporting the market's financial sustainability. For all cases, the dynamic increase in retail electricity tariffs and system size are the key determining factors for achieving profitability.

Considering the base case, which represents returns based on the current policy status for PV in SA, systems installed at the present time tend to be sized in order to maximize self-consumption over generation, since there is no remuneration for exported electricity. Thus, the current policy represents an unfavorable scenario for potential residential PV system investors; however, PV can still bring savings if the system is designed optimally.

Figure 13 analyses the variation in NPV resulting from different system sizes. For the base case (without support) and Case $3: \mathrm{NB}^{7}$, increased probabilities of profitability are indicated for smaller

\footnotetext{
${ }^{6}$ Range in which $90 \%$ of the occurrences can be found.

${ }^{7}$ Injection prices are assumed to remain constant $(0.04 € / \mathrm{kWh})$ in order to maintain comparability.
} 
systems that operate primarily for supplying household base load and that avoid surplus electricity export. Case 3: NB has slightly higher revenues because surplus electricity is purchased by the distributor at a pre-defined rate; however, revenues are not enough to compensate for the higher initial cost of a larger system.

Figure 13 - Sensitivity analysis for NPV according to system size variation for all cases

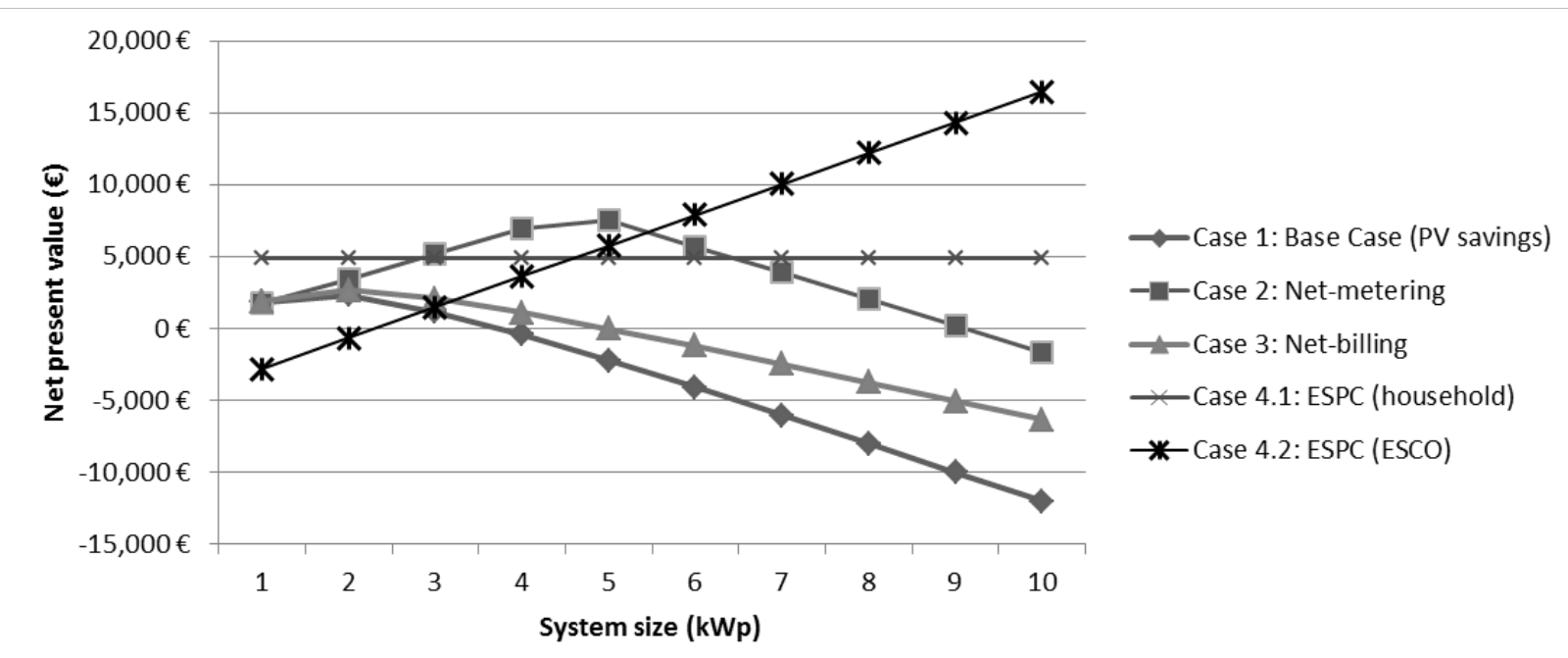

Case 2 (Net-metering) follows the same trend but the maximum NPV is achieved for larger systems than for Case 3 (NB). Maximum NPV occurs at the point that compensation in electricity costs reaches the maximum share possible of total household demand. The expenses related to larger systems are not compensated by the electricity bill savings, resulting in a surplus of electricity that has no useful purpose for the PV owner since it will be exported without recompense.

For Case 4.1 (ESPC/Household) and Case 4.2 (ESPC/ESCO), profitability varies with system size. Assuming that contract conditions are the same regardless of the system size ${ }^{8}$, profitability is likely to happen for both household and ESCO and profits increase proportionally with system size.

This analysis illustrates the imperative for the timely and effective implementation of a residential PV market framework in SA. A support strategy designed to favor PV installations sized for maximizing self-consumption over generation could result in loss of revenues for local distributors, whilst the continuation of the current policy status means little or no benefit for local distributors. If business models such as an NM, NB or ESCO framework were implemented, expansion of the PV market could in contrast represent a source of revenues for the local electricity distributors. Furthermore, systems designed to maximize savings could be a disadvantage when if business models which promote electricity trading are subsequently implemented.

It is apparent that risk for householders is reduced by a commitment from the local distributor or ESCO to purchase surplus electricity generated by the PV system. As for the local distributor or the ESCO, this purchase could be planned as an investment of expanding capacity of supply using a reliable and sustainable source of energy, or even as a distribution network infrastructure cost deferral mechanism, especially if the distributor or the ESCO retains ownership and control of the assets, and a 'smart' implementation of time-of-use tariffs or active export control technology is utilized. This ESPC business case analysis also serves as a basis for more detailed further investigation, for example, of shared ownership and control or leasing arrangements between household and ESCO.

\footnotetext{
${ }^{8}$ Assumption adopted in order to keep comparability, although it is likely not to be true as contracts between households and the ESCO’s will vary according to system size.
} 
The risk assessment for each business case shows that it is possible to mitigate household PV investment risks by establishing appropriate business practices, such as the case with NM and ESPC models. Furthermore, for business models that are less exposed to externalities, such as increases in retail electricity rates and export tariffs, investment risk is mitigated and thus facilitating more competitive PV market penetration in the residential sector. The analysis also shows that PV energy market competitiveness can be engendered by business models that do not involve explicit subsidies. However, since residential PV is not yet part of conventional business models for electricity trading, it requires the creation of appropriate mechanisms in order to contribute to an increase in PV penetration in the market.

\section{Conclusions}

A methodology for analyzing competitiveness of PV for the residential sector in South Africa has been presented in this work. This consists of evaluating investment risks using the concept of socket parity and a probabilistic discounted net cash flow analysis using Monte Carlo modelling.

The subsequent risk analysis for a case study household using a range of business models defines the probabilities of PV profitability for each of these models. The model also acts as a domestic sector PV policy decision support tool that clarifies specific solutions for managing risks. This is especially of value to policy makers when designing mechanisms to reduce the major sources of risk, assuming that there is political will to support domestic PV.

The application of the methodology in a case study on the current status of residential PV competitiveness in South Africa indicates that the market is on the threshold of attaining socket parity; however, the financial risk assessment show that the high level of uncertainties associated to such an investment potentially discourages household investors. Therefore, the level of PV market competitiveness may be considered as low in the current residential PV segment in South Africa due to the high associated investment risks.

The risk and uncertainty analysis also shows that financial performance of a residential PV system in South Africa is highly sensitive to future electricity tariff price trajectories and to system size. For the current policy context in which no remuneration is given for exported electricity to the grid, the analysis suggests that the PV system should be designed to maximize self-consumption over PV system generation.

Three new business models are proposed in order to improve the domestic PV market competitiveness: Net-metering; Net-billing; and Energy Savings Performance Contracts. The financial performance and risks for each case were analyzed and of all models evaluated, the Netmetering and the Energy Savings Performance Contracts presented relatively high probabilities of improving PV competitiveness in South Africa. An Energy Savings Performance Contract model presents even greater potential due to the transfer of capitalization risk from the householder to a third party more capable of managing this type of risk.

From the analysis it is possible to observe that risk assessment can help formulate decisions for both investors and policy makers in order to offer improved business solutions. Business models designed with the purpose of minimizing investment risk for both households and electricity distributors are likely to be more financially sustainable and improve the long term competitiveness of the residential PV market, and such pioneering businesses models may be seen as necessary to create successful market-driven solutions for the deployment of PV in the residential sector in emerging markets such as South Africa. Given that the context for PV technology implementation is changing rapidly, with reducing system costs, improved performance and the diffusion of smart meter technologies, there are opportunities for governmental authorities, market players and other stakeholders to avoid the need for excessive or long term subsidy frameworks which can cause 
burden to public finances, and instead move to business models that are self-sustaining financially and thus more attractive to all stakeholders.

\section{Recommendations for strategy development in emerging PV energy markets}

- Current and future policy frameworks for the expansion of PV capacity should recognize distributed generation within the residential PV market as a reliable and clean source of energy within the wider generation mix. Households with the ability of producing surplus electricity via domestic PV systems are therefore both consumers and valuable producers of electricity - namely 'prosumers'.

- New policy frameworks should be tailored to create favorable conditions for innovative market practices aimed at reducing investment risks for key stakeholders in the residential PV energy market.

- It is possible in markets such as South Africa to move away from residential sector PV subsidies to more market oriented frameworks in the short term.

- Stakeholders such as electricity distributors should be the leaders of residential PV market growth as there is significant potential for increasing revenues if PV is considered to be integral with the provision of energy services. The design of new business models considering PV system transfer or shared ownership between household and local distributor could provide significantly reduced risks for both parties.

- Innovative market solutions should be supported by governmental policy for an innovation industry through research and development on the economics of RE technologies.

- High income customers are likely to be 'early adopters' of PV as they represent the demographic that are willing and able to afford investment risks initially. Since they also represent the category of customer that spends the most on electricity.

- Without the strategic implementation of an intelligent market model, this means a loss of a potential new revenue stream for distributors. If this is the case, any increase in electricity prices will most likely affect lower income households in SA.

- Energy savings performance contracts could benefit lower income households not only in terms of financial savings but allowing the possibility access to more affordable electricity supply and therefore supporting quality of life improvement.

\section{References}

[1] Solar Power Europe. (2015). Global Market Outlook for Solar Power 2015-2019.

[2] PV Parity Project. (2013). How to Support Different Photovoltaic Applications in the Achievement of Competitiveness and Beyond. Supported by Intelligent Energy Europe.

[3] Breyer, C., \& Gerlach, A. (2013). Global Overview on Grid-Parity Event Dynamics. Progress in Photovoltaics: research and applications, 21, S. 121-136.

[4] Branker, K. et al. (2011). A review of solar photovoltaic levelized cost of electricity. Renewable and Sustainable Energy Reviews, 4470- 4482.

[5] Huld, T., Gottschalg, R., Beyer, H. G., \& Topic, M. (2010). Mapping the performance of PV modules, effects of module type and data averaging. Solar Energy 84, S. 324-338.

[6] IRENA, 2015. Analysis of Infrastructure for Renewable Power in Eastern and Southern Africa. International Renewable Energy Agency. 
[7] South African Electricity Supply Industry. (2008). Electricity Pricing Policy. Government notice, Department of Minerals and Energy, 19 December 2008.

[8] Bischof-Niemz, D. T. (2013). Potential for Embedded PV Generators in South Africa. Prasentation at the SAEEC. Johannesburg: Eskom.

[9] Pegels, A. (2010). Renewable Energy in South Africa: Potentials, barriers and options for support. Energy Policy, S. 4945-4954.

[10] ESKOM (2015). Historical average prices. Available at http://www.eskom.co.za/CustomerCare/TariffsAndCharges/Pages/Tariff_History.aspx. Accessed 25 June 2015.

[11] Department of Energy. (2013). Integrated Resource Plan for Electricity (IRP) 2010-2030.

[12] Berhard, A., Kolker, J., \& Leigland, J. (2014). South Africa's Renewable Energy IPP Procurement Program: Success Factors and Lessons. World Bank Group, Enabling Infraestructure Investment.

[13] Department of Energy. (2015). Preferred Bidders’ Announcement. Renewable Energy IPP Procurement Programme.

[14] Centre for Renewable and Sustainable Energy Studies (2013). Unlocking the Rooftop PV Market in South Africa. Accessed August 2014. Available at http://www.crses.sun.ac.za/files/research/publications/technicalreports/Unlocking\%20the\%20Rooftop\%20PV\%20Market\%20in\%20SA_final.pdf.

[15] International Energy Agency (IEA). (04. November 2014). In more places, solar PV reaches the crucial level of "socket parity". Acessed November 2014. Available at http://www.iea.org/ieaenergy/issue7/in-more-places-solar-pv-reaches-the-crucial-level-of-socketparity.html

[16] D.L. King, W.E. Boyson, J.A. Kratochvill (2004). Photovoltaic Array Performance Model. Sandia Report. Sandia National Laboratories.

[17] Microcare. (2014). Single Phase Grid Tie Solar Inverters (4000/5000W). Acessed September 2014. Available at Sustainable.co.za: http://www.sustainable.co.za/microcare-5kw-single-phasegrid-tied-inverters-solar-inverter.html.

[18] SMA. (2014). Technical Data Sunny Boy 3000 / 4000.

[19] Renesola. (September 2014). Technical Data Replus 4000/5000/6000TL3EL. Available at http://www.renesola.com/renesola-5kw-400v-50-60hz-grid-tied-solar-inverter-three-phase-2-mpptdc-input-600v-web-monitor-dc-switch-wi-fi-china-1637/.

[20] Huld, T., Gottschalg, R., Beyer, H. G., \& Topic, M. (2010). Mapping the performance of PV modules, effects of module type and data averaging. Solar Energy 84, S. 324-338.

[21] Huld, T., Suri, M., \& Dunlop, E. D. (22. July 2008). Geographical Variation of the Conversion Efficieny of Crystalline Silicon Photovoltaic Modules in Europe. Progress in Photovoltaics: Research and Applications 16, S. 595-607.

[22] Malik, A., \& Damit, S. (2003). Outdoor testing of single crystal silicon solar cells. Renewable Energy 28, S. 1433-1445.

[23] Fuentes, M. (1985). Thermal Characterization of Flat-Plate Photovoltaic Arrays. Alburquerque, New Mexico: Sandia National Laboratories.

[24] Renesola. (2014). Virtus II Module 250W, 255W, 260W Technical Specification. 
[25] SunPower. (2014). 215 Solar Panel Technical data.

[26] Yingli Solar. (2014). YGE 60 cell 40mm Series Data Sheet.

[27] JA Solar Holdings Co. Ltd. (2014). JA Solar JAP6 60/245-265/3BB Multicrystalline Silicon Module.

[28] Solar World. (2014). Sunmodule 230/235/240/245/250 poly Datasheet.

[29] World Bank. (2014). World Bank Development Indicators by Country. South Africa.

[30] South African Reserve Bank. (2014). Selected historical rates. Acessed November 2014. Available at https://www.resbank.co.za/

[31] Eskom. (April 2014). Tariff \& Charges Booklet 2014/2015.

[32] City of Tshwane Metropolitan Municipality. (23. July 2014). Electricity tariffs as approved by the National Electricity Regulator of South Africa (NERSA).

[33] City of Tshwane Update. (June/July 2014). New budget aims to sustain a financially resilient Tshwane. Accessed: August $2014 . \quad$ Available at: http://www.tshwane.gov.za/sites/residents/TSHWANE\%20UPDATE\%202014/Tshwane\%20Updat e\%20Edition\%203.pdf.

[34] National Energy Regulator of South Africa (NERSA) (2015). NERSA approved tariffs. Accessed: 15 June 2015.Available at: http://www.nersa.org.za/.

[35] Bischof-Niemz, D. T. (September 2014). Conference call on PV competitiveness in SA. (S. Betz, Interviewer)

[36] Huld, T., \& Jäger-Waldau, A. S. (2014). Mapping the cost of electricity from grid-connected and off-grid PV systems in Africa. 1st Africa Photovoltaic Solar Energy Conference and Exhibition, (S. 151-155). Durban, South Africa.

[37] Dekker, J., Nthontho, M., Chowdhury, S., \& Chowdhury, S. (March 2012). Economic analysis of PV/diesel hybrid power systems in different climatic zones of South Africa. Electrical Power and Energy Systems 40, S. 104-112.

[38] photovoltaik-guide.de. (2014). Photovoltaik-Preisindex. Acessed September 2014. Available at: http://www.photovoltaik-guide.de/pv-preisindex

[39] Bischof-Niemz, D. T. (27. March 2014). Renewables and PV Research and Implementation in South Africa. Presentation at the Africa PV SEC. Durban, South Africa.

[40] Haw, D. C. (May 2013). Overview of Solar PV in South Africa. South African Photovoltaic Industry Association (SAPVIA). Accessed August 2014. Available at: http://www.sapvia.co.za/wpcontent/uploads/2013/05/African-Utility-Week-Presentation-May-2013.pdf.

[41] European Central Bank. (2015). Euro exchange rates ZAR. Retrieved on the 23.06.2015: https://www.ecb.europa.eu/stats/exchange/eurofxref/html/eurofxref-graph-zar.en.html.

[42] Statistics South Africa. (18. June 2014). General household survey 2013. Statistical release P0318. Pretoria.

[43] Southern Africa Alternative Energy Association. (7. September 2013). Net-metering approval South Africa. Acessed November 2014. Available at SAAEA: http://www.saaea.org.

[44] Southern Africa Alternative Energy Association. (30. September 2014). City of Cape Town launches small scale embedded energy generation guidelines and tariffs. Acessed November 2014. Available at SAAEA: http://www.saaea.org 
[45] Barnard, H. (2014). Municipal tariffs: where to from where? Acessed November 2014. Available at: http://www.ameu.co.za/.

[46] Frantzis, L., Graham, S., Katofsky, R., \& Sawyer, H. (2008). Photovoltaics Business Models. National Renewable Energy Laboratory.

[47] European Association of Energy Services Companies. (2011). Energy Performance Contracting in the European Union.

[48] North Carolina Solar Centre. (2014). Integrating Solar PV into Energy Savings Performance Contracts: Options for Loval Governments Nationwide. 